\title{
Un Siglo de Pensamiento Iberoamericano
}

CON este título podría traducirse el todavia reciente e interesante libro A Century of Latin American Thought, escrito por William Rex Crawford, agregado cultural de Estados Unidos de Norteamérica en el Brasil, además de catedrático de la Universidad de Pennsylvania, editado por la Harvard University Press en 1944, y reimpreso en 1945, reimpresión inmediata que es ya un buen índice de los merecimientos de la obra.

$\mathrm{El}$ autor expone el pensamiento de alrededor de cuarenta y cinco pensadores iberoamericanos, los más importantes, en los que la influencia europea es más fuerte que ninguna otra. Desde un punto de vista general, la separación entre la América de habla inglesa y la de habla española era mucho mayor, a nuestro juicio, hace treinta años que hoy. Al menos, en nuestros días hay ya ciertos puntos de contacto facilitados por una mayor intercomunicación y un notable cambio en la actitud de Estados Unidos hacia los países iberoamericanos, actitud que mantuvo y acentuó sincera y notablemente el que fué insigne Presidente de aquéllos, F. D. Roosevelt. No es preciso, ni en realidad lo será nunca, que el pensamiento en ambas Américas sea homogéneo, pero sí que haya un mayor acercamiento entre una y otra y esto se obtiene con un mejor conocimiento del pensar de los hombres dirigentes, y no precisamente en lo político, de los pensadores de una y otra América. Tal mejor entendimiento será facilitado por el libro que nos ocupa, que mostrará a los norteamericanos la actitud fundamental del pensamiento de los iberoamericanos respecto a los grandes problemas de la vida. 
Certeramente expone Crawford el hecho de que el pensar hispanoamericano se inclina más hacia lo formal que hacia lo real y que hay una acentuación hacia lo personal que no por ello excluye, ni mucho menos, al positivismo. Para el autor, la prevalencia de lo positivo es la característica, o al menos una de ellas, del pensamiento norteamericano, positivismo que se da en menor medida entre los iberoamericanos, con excepción de la Argentina, en donde hay una mayor acentuación del mismo.

Quizá en este punto quepa hacer alguna observación y es que el positivismo, en general, ha sido también la característica que ha predominado, salvo excepciones, en la filosofía, la sociología y la educación de los países iberoamericanos, al menos hasta bastante avanzado el siglo actual. Ese positivismo coincidió adecuadamente con exigencias histórico-políticas de dichos países, especialmente con la formación de los mismos como naciones indepenđientes, en las cuales inicialmente - $-y$ ello fué visible en la Argentina - predominaba un cierto utilitarismo. Lo que sucedió y aún sucede es que el positivismo iberoamericano difiere del norteamericano. En tal sentido, creemos pueden aducirse varios razonamientos, entre otros, ciertos orígenes en la formación cultural de unos y otros países. La aceptación y difusión del positivismo en Estados Unidos se halla favorecida por un pronunciado sentido utilitarista y una actitud antiintelectualista que conduce, más tarde, a un acentuado pragmatismo que ahora ha sido en buena parte corregido. En los países iberoamericanos existió siempre y existe aún cierto sedimento "romántico", una acentuación de lo intelectual, con propensión a lo puramente teórico y un agudo personalismo, todo lo cual lleva a un positivismo de índole acusadamente formalista, teórico más que efectivo, contra el que se reacciona hoy en ciertos países, señaladamente en México y la Argentina. En esta última la corriente de repulsa deriva una vez más de Europa, pero es también allí donde el positivismo jurídico está tomando más auge en diversas formas, especialmente a través de un kelsenismo que es perduración de un formalismo. Actualmente, la Argentina sigue desempeñando un papel preponderante en el desarrollo del pensamiento iberoamericano.

Crawford hace una correcta exposición sistemática y pone de manifiesto, en el primer capítulo, la conexión existente entre independencia y nacionalidad, ocupándose en él de Sarmiento, Echeverría y Alberdi, siendo éste el que más acusadamente presenta influen- 
cias del utilitarismo inglés. La figura de Andrés Bello es examinada en el capítulo iru con las de Lastarria, Bilbao y Letelier, constituyendo todas ellas el ciclo chileno. Al final del capítulo se refiere a Enrique Molina, una de las personalidades más valiosas del pensamiento chileno actual; a doña Amanda Labarca, infatigable educadora y a Ricardo A. Latcham.

El capítulo IV se halla dedicado a Rodó y Vaz Ferreira, uruguayos. El primero es el creador y mantenedor de la tesis "arielista", hoy en verdad $-\mathrm{y}$ afortunadamente - superada. Al positivismo e idealismo argentinos, se halla consagrado el capítulo $v$, en el que se estudian las eminentes figuras de Alvarez Suárez, Bunge, Arguedas, González, Ingenieros, Korn, Ugarte, Gálvez y Rojas, El pensamiento de Alvarez lo examina cuidadosamente y pone de manifiesto el sano y constructor antiformalismo de su obra y su lucha contra ese mundo de apariencias, al cual se sigue apegado en cierta medida en determinados lugares de Iberoamérica, mundo que se caracteriza por un sentido reverencial de las opiniones y no de los hechos. Esto hace que las palabras de Alvarez tengan aún actualidad, sobre todo cuando declara que debe aprenderse la lección de que las palabras no implican la existencia de las cosas que las mismas nombran. La figura de Ingenieros es amplia y objetivamente analizada $y$ se hace resaltar la infatigable obra suya y la gran influencia que él mismo ejerció y que todavía pervive. El pensamiento de Ingenieros se halla detenidamente expuesto y revela en Crawford, una vez más, una seria investigación y conocimiento de una de las más grandes figuras del pensamiento iberoamericano.

En este capítulo netamente argentino se halla incluído Alcides Arguedas, boliviano, al que el autor señala como admirador y seguidor de Bunge, hecho que si bien puede explicar, y sólo relativamente, la inclusión, no justifica el silencio sobre otros pensadores bolivianos. Hay aquí una omisión que debe ser salvada por el autor, ya que en tierras andinas existen nombres que son dignos de ser mencionados. No vamos a exigir, por lo dicho, un estudio detenido del interesante pensador boliviano Oyola Cuéllar, poco conocido en su misma patria, pero sí una referencia al mismo y otras a Reyes Ortiz, San Román y. algunos más y, desde luego, las más actuales de Franz Tamayo y Roberto Prudencio, cuyas propias personalidades y concepciones no siguen, ni mucho menos, la orientación argentina y justificarian con las anteriores un capítulo dedicado a Bolivia y sus pensadores. 
La mención, merecida desde luego, de Alcides Arguedas, que es un gran novelista y ensayista, no basta a cubrir el silencio con relación a los pensadores bolivianos citados.

Al Pacífico se dedica el capítulo vi, con las figuras de Montalvo, González Prada y Mariátegui, pasando después al Brasil, del que se estudian los siguientes pensadores: Da Cunha, Bomfim, Freyre, haciéndose referencias a otros más. De Cuba son estudiados Varela, Luz y Caballero, Saco, Varona y Martí, y de Puerto Rico, el gran Hostos, a quien reputa como pensador más sistemático que Sarmiento. Crawford señala certeramente la índole introvertida de Hostos, que contribuyó con otros factores a que su obra fuera y sea aún no debidamente conocida.

E1 capítulo Ix se halla dedicado a los mexicanos. Comienza con Mora, sigue con Ramírez, Altamirano, Sierra (muy influído éste por Spencer), Bulnes y Vasconcelos - ampliamente estudiado- y termina con Caso, a quien dedica un extenso estudio. Para nosotros, Caso es una de las figuras prominentes del pensamiento americano actual y uno de los más firmes superadores del positivismo que tanto influjo ejerció en México.

El libro de Crawford revela un serio trabajo de investigación y un vasto conocimiento del pensar iberoamericano. También, y ello es importante, un esfuerzo de mérito en pro de un entendimiento y acercamiento de las dos Américas, cuya diversidad intelectual es consecuencia de la cultura que significa pluralidad de pensamiento, ya que aquélla se halla en estrecha correlación con la personalidad, y las dos Américas, si políticamente y en defensa de la democracia. deben constituir un bloque, culturalmente no tienen por qué serlo, en cuanto reflejan personalidades diversas.

Esa diversidad del lado iberoamericano ha sido bien investigada. y estudiada por Crawford, norteamericano, que ha interpretado objetivamente el pensamiento, en muy diversos aspectos de un buen número de países de habla española. Su libro debe ser conocido no. sólo en Norteamérica, sino también entre nosotros, y bueno fuera que se realizara su traducción al español para que se difundiera en las universidades iberoamericanas y en el público en general, ya que la obra de Crawford merece, por su trabajo seriamente realizado y por su finalidad, ser conocida con mayor amplitud.

Manuel López Rey, Universidad de La Paz, Bolivia. 